\title{
PRODUCTION OF AN EXTRACELLULAR HALOPHILIC AMYLASE FROM THE EXTREMELY HALOPHILIC ARCHAEON NATRIALBA AEGYPTIACA STRAIN 40
}

\author{
NOURA S. A. HAGAGGI ${ }^{1}$, FRANCIS F. HEZAYEN ${ }^{1}$ AND USAMA M. ABDUL- \\ RAOUF $^{2}$ \\ ${ }^{1}$ Botany Department, Faculty of Science, Aswan University, 81528 Aswan, Egypt \\ ${ }^{2}$ Botany and Microbiology Department, Faculty of Science, Al-Azhar University, \\ Assiut Branch, 71542 Assiut, Egypt (Corresponding author ).
}

\begin{abstract}
The extremely halophilic archaeon, Natrialba aegyptiaca strain $40^{\mathrm{T}}$, which was isolated from a salty soil close to Aswan, Egypt is able to produce a halophilic extracellular, raw starch-digesting amylase. Optimization of medium components and culture conditions to enhance amylase production was investigated. Maximum production of this amylase was achieved in a medium contained (\%, w/v): $\mathrm{NaCl}, 15 ; \mathrm{KCl}, 1.5 ; \mathrm{MgSO}_{4} .7 \mathrm{H}_{2} \mathrm{O}, 0.1$ and soluble starch, 0.05 at a $\mathrm{pH}$ range between 6-8 and a temperature range between $45-47{ }^{\circ} \mathrm{C}$ after incubation period of $144 \mathrm{hr}$. under static conditions and $48 \mathrm{hr}$. with shaking at $150 \mathrm{rpm}$. The enzyme could efficiently hydrolyze raw starches from different plant sources.
\end{abstract}

Key words: halophilic, Natrialba aegyptiaca, amylase, production, optimization, raw starches

\section{Introduction}

Extremely halophilic archaea are microorganisms that can grow best in media containing 2.5-5.2 M (i.e. 15-32 \%, w/v) NaCl (Kushner \& Kamekura, 1988). They dominate the microbial populations of hypersaline environments (Ventosa, 2006). Enzymes from organisms grown in extreme environments have proven to be useful for industrial processes (Niehaus et al., 1999). Amylases are one of the most important industrial enzymes, they are extracellular hydrolytic enzymes which hydrolyze starch polymers to give diverse products including dextrin and progressively smaller polymers composed of glucose units (Windish \& Mhatre, 1965; Horváthová et al., 2000). They are considered as a class of industrial enzymes, having approximately $25 \%$ of the world enzyme market. These enzymes are of great importance in the present day biotechnology and they cover many industrial applications such as food fermentation, sugar, brewing, distilling, textile, paper industries, and pharmaceuticals (Pandey et al., 2000; Saxena et al., 2007; Rajagopalan \& Krishnan, 2008). Although amylases can be obtained from several sources including plants, animals and microorganisms, the microbial enzymes generally meet the expanding industrial demands. Today a large number of microbial amylases are commercially available and they have, nearly, completely replaced the chemical hydrolysis of starch in starch processing industry (Pandey et al., 2000). Although many amylases of various microorganisms have been studied, there are relatively fewer studies focused on archaeal amylases (Jones et al., 1999; Hutcheon et al., 2005). Halophilic archaeal amylases have been characterized, e.g., 
from Halobacterium halobium, Natronococcus amylolyticus, Haloferax mediterranei, Haloarcula sp. S-1 and Haloarcula hispanica (Good \& Hartman, 1970; Kobayashi et al., 1992; Pérez-Pomares et al., 2003; Fukushima et al., 2005; Hutcheon et al., 2005). Optimization of fermentation conditions, particularly physical and chemical parameters, is important in the development of fermentation processes due to their impact on the economy and practicability of the process (Francis et al., 2003). The effect of various factors such as $\mathrm{NaCl}$, substrate, $\mathrm{KCl}$ and $\mathrm{MgSO}_{4} \cdot 7 \mathrm{H}_{2} \mathrm{O}$ concentration as well as incubation period, temperature and $\mathrm{pH}$ have been previously studied (Good \& Hartman, 1970; Oren, 1983; Kobayashi et al., 1992; Pérez-Pomares et al., 2003; Fukushima et al., 2005; Hutcheon et al., 2005). The physical and chemical parameters that affect the production of amylases by the halophilic archaea, Halobacterium halobium, Natronococcus amylolyticus, Chromohalobacter sp. TVSP101 and Haloarcula hispanica have been widely studied and described (Gupta et al., 2003). Raw starches are the dominant amylase substrates amongst different substrates that exists in nature. It is therefore surprising that few $\alpha$-amylases appear to be capable of hydrolyzing this substrate in its native state (Hamilton et al., 1999; Nidhi et al., 2005). Amylases are used extensively in the industry, particularly in the liquefaction of starch but due to the inability of these enzymes to hydrolyze the native substrate efficiently, starch is firstly gelatinized prior to enzymatic degradation (Hamilton et al., 1999; Nidhi et al., 2005). This paper deals with production capability as well as productivity's optimization of the raw starch-digesting amylase from the halophilic archaeon Natrialba aegyptiaca strain $40^{\mathrm{T}}$.

\section{Materials And Methods}

\section{Archaeal strain, growth conditions and media used}

The extremely halophilic archaeon Natrialba aegyptiaca strain $40^{\mathrm{T}}$ was isolated from a salty soil close to Aswan, Egypt. It was obtained kindly from Dr. Francis F. Hezayen (coauthor). It is deposited in the DSMZ as DSM $13077^{\mathrm{T}}$ and in Japan Collection of Microorganisms, Wako, Saitama, Japan as JCM $11194^{\mathrm{T}}$ (Hezayen et al., 2001; Hezayen, 2002).

Growth and maintenance medium: The strain was grown and maintained on proteose peptone salt medium which contained (\%, w/v): $\mathrm{NaCl}, 25 ; \mathrm{KCl}, 0.2$; $\mathrm{MgSO}_{4} .7 \mathrm{H}_{2} \mathrm{O}, 0.5$; proteose peptone, 0.75 and yeast extract, 0.5 ; incubation period was 3 days.

Amylase production medium: which contained (\%, w/v): $\mathrm{NaCl}, 25 ; \mathrm{KCl}, 0.2$; $\mathrm{MgSO}_{4} .7 \mathrm{H}_{2} \mathrm{O}, 0.5$; emulsified soluble starch, 0.5 and agar, 2. incubation period was 5 days.

Starch salt agar medium: this medium was used to determine the amylase activity and contained (\%, w/v): $\mathrm{NaCl}, 25 ;$ Bacto-agar, 1.5 supplemented with emulsified soluble starch, 0.5 .

If otherwise is not indicated, $\mathrm{pH}$ of the media was adjusted to 7.0 with $0.1 \mathrm{~N} \mathrm{NaOH}$, sterilized by autoclaving and the incubation temperature was $40^{\circ} \mathrm{C}$. 


\section{Ability of Natrialba aegyptiaca strain $40^{\mathrm{T}}$ to produce extracellular amylase:-}

Amylase production was tested qualitatively in both, agar and broth cultivations, following the methods described by Amoozegar et al., (2003) and Ammar et al., (1998), respectiely. Agar plates and the broth of the amylase production medium were inoculated, and incubated for 5 days. Amylase production in agar plates was tested by flooding their surfaces with Lugol's iodine solution $\left(0.3 \% \mathrm{I}_{2}, 0.6 \% \mathrm{KI}\right)$ (Cowan, 1974), and in liquid growth by clear zone technique (CZT) as mentioned below. Appearance of clear zones indicates amylase production. This test indicated that strain 40 is strong amylase producer as previously mentioned (Hezayen et al., 2001; Hezayen, 2002).

Factors affecting productivity was studied as follows: the amylase production medium was dispensed in $250 \mathrm{ml}$ capacity Erlenmeyer conical flasks, 50 $\mathrm{ml}$ in each inoculated with $2 \mathrm{ml}$ of 3 -days old pre-culture containing $1 \times 10^{8}$ $\mathrm{CFU} / \mathrm{ml}$ and incubated for 5 days (If otherwise is not indicated). Then, growth was harvested, centrifuged for $30 \mathrm{~min}$. at $6000 \mathrm{rpm}$, and the amylase activity was determined in the supernatants.

\section{Determination of amylase activity:-}

Amylase activity from broth cultivations was determined according to the clear zone technique (CZT) of Elwan et al., (1986), standardized later by Ammar et al., (1998). In the plates of starch salt agar medium mentioned above, three cups were made in each plate using a sterile cork borer, each cup was filled with $0.25 \mathrm{ml}$ of the cell free supernatant and the plates were incubated at $40{ }^{\circ} \mathrm{C}$ for $48 \mathrm{hr}$., then flooded with Lugol's iodine solution. The diameters of clear zones were measured, the average was calculated and expressed in terms of units $/ \mathrm{ml}$ using amylase standard curve (Ammar et al., 1998).

\section{Factors affecting amylase production:-}

Effect of various factors such as $\mathrm{NaCl}, \mathrm{KCl}, \mathrm{MgSO}_{4} .7 \mathrm{H}_{2} \mathrm{O}$, substrate concentration, $\mathrm{pH}$, incubation temperature, incubation period, inoculum size and shaking rate as well as carbon and nitrogen sources on amylase production was tested. If otherwise is not indicated, factors were tested on the amylase production medium and amylase productivity was assayed as mentioned above.

\section{Effect of $\mathrm{NaCl}, \mathrm{KCl}$ and $\mathrm{MgSO}_{4} \cdot 7 \mathrm{H}_{2} \mathrm{O}$ :-}

To determine the effect of these salts on the amylase productivity of strain $40^{\mathrm{T}}$, different concentrations from each was tested i. e. for $\mathrm{NaCl}, 5.0,8.0,10.0,12.5$, 15.0, 17.5, 20.0, 22.5, 25.0, 27.5, 30.0 and 32.0; for $\mathrm{KCl}, .0 .0,0.01,0.05,0.1,0.2$, $0.3,0.4,0.5,0.6,0.7,0.8,0.9,1.0,1.5,2.0,2.5$ and 3.0 and for $\mathrm{MgSO}_{4} .7 \mathrm{H}_{2} \mathrm{O}, 0.0$, $0.01,0.05,0.1,0.2,0.3,0.4,0.5,0.6,0.7,0.8,0.9,1.0,1.5$ and $2.0(\mathrm{~g} \%, \mathrm{w} / \mathrm{v})$. Amylase productivity was assayed as mentioned above.

\section{Effect of substrate (soluble starch) concentration:-}

This was performed, applying different concentrations i.e. $0.0,0.01,0.05,0.1$, $0.25,0.5,0.75,1.0,1.5,2.0,2.5,3.0$ and $3.5(\mathrm{~g} \%$, w/v) from soluble starch. Amylase productivity was assayed as mentioned above. 


\section{Effect of $\mathrm{pH}$, incubation temperature and incubation period:-}

The effect of temperature on amylase productivity was measured in the range of 10 ${ }^{\circ} \mathrm{C}$ to $70{ }^{\circ} \mathrm{C}$ while the effect of $\mathrm{pH}$ was measured in the range of 4 to $10(0.5$ intervals), $\mathrm{pH}$ was adjusted by either $\mathrm{HCl}$ or $\mathrm{NaOH}(0.1 \mathrm{~N})$ and for the incubation period, different incubation periods were applied i.e. 24, 48, 72, 96, 120, 144, 168, 192, 216 and 240 hour. Amylase productivity was assayed as mentioned above.

\section{Effect of inoculum size:-}

Different inocula sizes of a standard suspension of 3-days old culture of Natrialba aegyptiaca strain $40^{\mathrm{T}}$ were tested i.e. $0.1,0.2,0.5,1,1.5,2.0,2.5,3.0,3.5$, 4.0, 4.5, 5.0, 5.5 and $6.0 \mathrm{ml}^{-1} /$ flask. Each $1 \mathrm{ml}^{-1}$ of suspension contained $1 \times 10^{8}$ $\mathrm{CFU} / \mathrm{ml}$. Amylase productivity was assayed as mentioned above.

\section{Effect of shaking rate:-}

This was performed by incubating the inoculated flasks in a shaking incubator (optic ivymen ${ }^{\circledR}$ system, $100 \mathrm{D}$ ) at different shaking speeds i.e. 50, 100, 150, 200, 250,300 and $350 \mathrm{rpm}$ at $40{ }^{\circ} \mathrm{C}$. Amylase productivity was assayed as mentioned above.

\section{Effect of different carbon sources:-}

Various carbon sources such as soluble starch, corn, rice, potato, wheat, beans starch (Phaseolus vulgaris) as well as dextrin, glycogen, carboxymethyl cellulose, glucose, lactose, maltose, sucrose, xylose, glycerol and mannitol were tested, where the amylase production medium was supplemented with $0.5 \%(\mathrm{w} / \mathrm{v})$ of the desired substance. Then the enzyme productivity was assayed as mentioned above.

\section{Effect of different nitrogen sources:-}

The effect of different inorganic and organic nitrogen on amylase productivity was determined. The amylase production medium was supplemented with $0.1 \%$ (w/v) of the inorganic sources; $\mathrm{NH}_{4} \mathrm{Cl}, \mathrm{NaNO}_{3}, \mathrm{NH}_{4} \mathrm{NO}_{3},\left(\mathrm{NH}_{4}\right)_{2} \mathrm{SO}_{4}$, $\left(\mathrm{NH}_{4}\right)_{3} \mathrm{PO}_{4}$ as well as of the organic sources; peptone, protease peptone, gelatin, yeast extract, casamino acids, casein, skim milk, fresh milk, meat casein, beef extract, tryptone and fibrin. Productivity was assayed as mentioned above.

\section{Effect of crude amylase on raw starch from different plant sources:-}

The ability of amylase produced by Natrialba aegyptiaca strain $40^{\mathrm{T}}$ to digest_raw starch from different sources was tested following the method described by Hamilton et al. (1999) with some modifications as follows; 0.5 gm of raw starch grains i.e. of each of corn, rice, potato, wheat and beans was ground and incubated with $5 \mathrm{ml}$ of crude amylase in $5 \mathrm{ml}$ of $0.1 \mathrm{M}$ citrate buffer at $40{ }^{\circ} \mathrm{C}$ for $1 \mathrm{hr}$. Soluble starch was used as control. After that the reaction mixture was boiled to stop amylase action and then centrifuged at $6000 \mathrm{rpm}$ for $30 \mathrm{~min}$. The amylase activity was assayed in the supernatant using the iodometric method (Pantschev et al., 1981) as follows; $1 \mathrm{ml}$ of the supernatant was taken in a clean test tube and $1 \mathrm{ml}$ of $0.01 \mathrm{~N}$ iodine solution was then added. The amylase activity was measured spectrophotometrically at $580 \mathrm{~nm}$. The activity was calculated in unit/ml using 
amylase standard curve. One unit of activity was defined as the amount of enzyme that hydrolyzes $0.5 \mathrm{gm}$ of starch to dextrin per minute.

\section{Results And Discussion}

The main aim of this work was to optimize the medium components and cultural conditions for amylase production by the extremely halophilic archaeon Natrialba aegyptiaca strain $40^{\mathrm{T}}$. This optimization plays a significant role in enhancing amylase production by various microorganisms (Good \& Hartman, 1970; Kobayashi et al., 1992; Pérez-Pomares et al., 2003; Fukushima et al., 2005; Hutcheon et al., 2005; Sajedi et al., 2005; Couto \& Sanromán, 2006; VijayAnand et al., 2010).

\section{Amylase production}

The amylase production by Natrialba aegyptiaca strain $40^{\mathrm{T}}$ was detected and determined on both solid (Fig.1.) and liquid (Fig.2.) production medium.

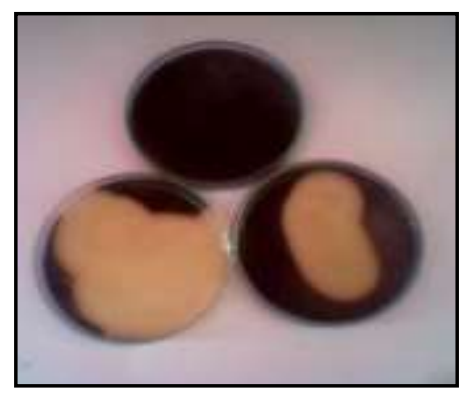

Fig.2.

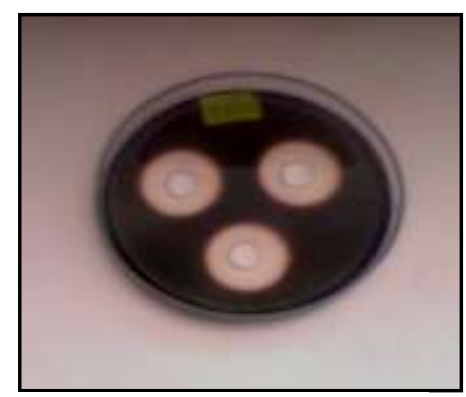

Fig.1.

Fig.1. detection of amylase productivity according to Amoozegar et al., (2003).

Fig.2. detection of amylase productivity using the CZT.

\section{Factors affecting amylase production:-}

The effect of each of $\mathrm{NaCl}, \mathrm{KCl}, \mathrm{MgSO}_{4} \cdot 7 \mathrm{H}_{2} \mathrm{O}$, substrate concentration, $\mathrm{pH}$, incubation temperature, incubation period, inoculum size and shaking rate as well as carbon and nitrogen sources on amylase production was tested as mentioned above.

\section{Effect of $\mathrm{NaCl}$ concentration:-}

As shown in figure (3) amylase production occurred within a broad range of $\mathrm{NaCl}$ concentrations, i.e. between 8 and $32(\%$, w/v). Production began at $8(\%$, $\mathrm{w} / \mathrm{v})$, and increased gradually till it reached its maximum rate $(30 \mathrm{unit} / \mathrm{ml})$ at $15(\%$, w/v), then decreased gradually. From 17.5 to $32 \mathrm{NaCl}$ (saturation) (\%, w/v), production rate was stable. This was corresponding to $\mathrm{NaCl}$ concentrations required for the strain's growth (Hezayen, 2002; Hezayen et al., 2001). On the other hand and in contrast with our foundation, the maximum amylase production by the extremely halophilic archaea Haloferax mediterranei and Haloarcula sp. strain S-1 occurred at $25(\%, \mathrm{w} / \mathrm{v}) \mathrm{NaCl}$, and $18.5(\%, \mathrm{w} / \mathrm{v})$ for Haloarcula hispanica (Pérez-Pomares et 
al., 2003; Fukushima et al., 2005; Hutcheon et al., 2005). This may be because Natrialba aegyptiaca strain $40^{\mathrm{T}}$ is adapted for growth at lower $\mathrm{NaCl}$ concentratins than most other extremely halophilic archaea which require more than $12(\%, \mathrm{w} / \mathrm{v})$ to grow (Hezayen, 2002; Hezayen et al., 2001).

\section{Effect of $\mathrm{KCl}$ concentration:-}

It is known that $\mathrm{K}^{+}$and $\mathrm{Cl}^{-}$play a very important role in the physiology and growth behavior of the extremely halophilic archaea, consequently enzymes' production. Halophilic archaea accumulate $\mathrm{K}^{+}$intracellularly, $4 \mathrm{M} \mathrm{KCl}$, for osmoregulation, cells integrity and adaptation of intracellular and extracellular enzymes for maintaining their activity and stability (Zaccai \& Eisenberg, 1990; Madern et al., 2000; Marhuenda-Egea \& Bonete, 2002). As shown in (Fig.4) amylases was produced in absence of $\mathrm{KCl}$, because $\mathrm{KCl}$ is important for the growth of halophilic archaea, we guess that the strain could use $\mathrm{KCl}$ which is present as contaminants in the other components of the production medium. Productivity was slightly stimulated by $\mathrm{KCl}$ until $1(\%, \mathrm{w} / \mathrm{v})$ and exhibited its maximum amylase production at $1.5(\%, \mathrm{w} / \mathrm{v}) \mathrm{KCl}$. The effect of $\mathrm{K}^{+}$ion on amylase production was observed also by Fukushima et al., (2005) who reported that the maximum amylase production by the extremely halophilic archaeon Haloarcula sp. S-1 occurred at 0.2 (\%, w/v) $\mathrm{KCl}$, while Hutcheon et al. (2005) found that the optimum $\mathrm{KCl}$ concentration required for the maximum amylase production by the extremely halophilic archaeon Haloarcula hispanica was $0.5(\%, \mathrm{w} / \mathrm{v})$.

\section{Effect of $\mathrm{MgSO}_{4} \cdot 7 \mathrm{H}_{2} \mathrm{O}$ concentration:-}

Various systems of halophilic enzymes require divalent ions such as $\mathrm{Mg}^{2+}$ for their activity and stability (Norberg et al., 1973; Lanyi, 1974). As shown in (Fig.5), the present strain showed maximum amylase production between 0.1 and $0.2(\%$, w/v) $\mathrm{MgSO}_{4} \cdot 7 \mathrm{H}_{2} \mathrm{O}$. Lower and higher concentrations inhibited slightly amylase production. The explanation of amylase production in the absence of $\mathrm{MgSO}_{4} \cdot 7 \mathrm{H}_{2} \mathrm{O}$ is that the strain could use $\mathrm{MgSO}_{4} .7 \mathrm{H}_{2} \mathrm{O}$ which is present as contaminants in the other components of the production medium. In, contrast, it was found that the maximum amylase production was exhibited at 2 and $2.7(\%, \mathrm{w} / \mathrm{v}) \mathrm{MgSO}_{4} \cdot 7 \mathrm{H}_{2} \mathrm{O}$ for the extremely halophilic archaea Haloarcula sp. S-1 and Haloarcula hispanica, respectively (Fukushima et al., 2005; Hutcheon et al., 2005).

\section{Effect of substrate (soluble starch) concentration:-}

It was found that substrate concentration has a great effect on amylases production by halophilic archaea. Interestingly, as shown in (Fig. 6), the present strain could produce amylase in the absence of starch. Although productivity was low, it indicates that strain 40 can synthesize amylase constitutively. It was observed that nearly, any addition of starch stimulates amylases production (Fig. 6). The maximum production was exhibited at $0.05(\%, \mathrm{w} / \mathrm{v})$ starch, This was in contrast with the foundations of Pérez-Pomares et al. (2003) and Fukushima et al. (2005) who reported that that the maximum amylase production by the extremely halophilic archaeon Haloferax mediterranei and Haloarcula sp. S-1 was exhibited at 0.2 and 1 $(\%, \mathrm{w} / \mathrm{v})$ soluble starch respectively. 


\section{Effect of pH:-}

$\mathrm{pH}$ of the production medium plays an important role in enzyme secretion. Change in $\mathrm{pH}$ during the growth of the organism affects product stability in the medium (Gupta et al., 2003). The pH values also serve as a valuable indicator of the initiation and the end of enzyme's synthesis (Friedrich et al., 1989). As it is shown in (Fig. 7), the amylase production by the strain 40 occurred at a wide $\mathrm{pH}$ range i.e. between 5 and 9, with maximum production between 6 to $8 \mathrm{pH}$. On the other hand, the maximum amylase production by the extremely halophilic archaeon Haloferax mediterranei was exhibited at $7.2 \mathrm{pH}$ (Pérez-Pomares et al., 2003). Fukushima et al. (2005) observed that $\mathrm{pH} 7.0$ stimulated the maximum production of amylase by the extremely halophilic archaeon Haloarcula sp. S-1. Moreover, Hutcheon et al. (2005) reported that the $\mathrm{pH} 6.5$ exhibited the maximum amylase production by the extremely halophilic archaeon Haloarcula hispanica.

\section{Effect of incubation temperature:-}

Temperature has a great effect on growth and amylase production by halophilic archaea. It was interesting to find that amylase production by the present strain occurred within a temperature range from 20 to $60{ }^{\circ} \mathrm{C}$ and maximum production was exhibited between 45 and $47{ }^{\circ} \mathrm{C}$ (Fig. 8). This was in contrast with the foundations of other workers who found that maximum amylase production by the extremely halophilic archaea Haloferax mediterranei and Haloarcula sp. strain S-1 was observed at $37{ }^{\circ} \mathrm{C}$ and for Haloarcula hispanica, was $50{ }^{\circ} \mathrm{C}$ (Pérez-Pomares et al., 2003; Fukushima et al., 2005; Hutcheon et al., 2005). This may be because the present strain adapted to the relatively high temperature which is characteristic to the location of isolation, Aswan in Upper Egypt.

\section{Effect of incubation period:-}

In contrast to eubacteria, extremely halophilic archaea are characterized by its long incubation periods, ranging from 4 to 21 days, or more in rare cases (Tomlinson \& Hochstein, 1972; Tindall et al., 1984; Montalvo-Rodriguez et al., 1998; Xin et al., 2000; Xu et al., 2001; Gutiérrez et al., 2007). As shown in (Fig.9), production of amylase by strain 40 was detected after an incubation period of $24 \mathrm{hr}$, it increased gradually with increasing incubation until it reaches its maximum within $144 \mathrm{hr}$ (6 days) under static condition This was in complete accordance with the foundations of Hutcheon et al. (2005) who found that the maximum amylase production by the extremely halophilic archaeon Haloarcula hispanica occurred within 6-7 days of incubation, and Fukushima et al. (2005), who reported that the maximum amylase production by the extremely halophilic archaeon Haloarcula $s p$. S-1 was observed after 7 days. Under shaking, at 150 round per minute (rpm), the maximum production was achieved after $48 \mathrm{hr}$ incubation, above which, productivity was constant. This because presence of high salt concentration in the production medium causes oxygen tension which affects significantly the growth of the strain and therefore the enzyme production, while with shaking, the aeration of the medium increased, leading to sufficient oxygen supply. This increased the rate of growth and subsequently the enzyme production increased (Kumar \& Takagi, 1999; Beg et al., 2003). 


\section{Effect of inoculum size:-}

As it is shown in (Fig. 10), inoculums' size has a great effect on amylase productivity. Production increase strongly with increasing the inoculums' size until it becomes constant. This may be because large inoculums decrease the lag or preparatory phase of growth. It was observed that $4 \mathrm{ml}^{-1} /$ flask (i.e. $8 \%$, v/v), $1 \mathrm{ml}^{-1}$ contained $1 \times 10^{8} \mathrm{CFU} / \mathrm{ml}$ of 3-days old inoculums of strain $40^{\mathrm{T}}$, exhibited the maximum amylase production, above which, productivity was constant.

\section{Effect of shaking rate:-}

As mentioned above, shaking accelerates reaching maximum productivity. As shown in Fig. (11), maximum amylase productivity was exhibited at $150 \mathrm{rpm}$, above this the enzyme production decreased. Productivity increased because shaking leads to sufficient supply of dissolved oxygen in the medium, consequently, nutrient uptake by the strain increased and subsequently the enzyme production increased (Kumar \& Takagi, 1999; Beg et al., 2003). Above $150 \mathrm{rpm}$, the amylase production decreased, this may be because, the higher shaking rates could increase the oxygen supply to the medium but did not bring about the increase in enzyme production, probably because at high shaking rates, the structure of the enzyme would be altered (Roychoudhury et al., 1988). It was reported that the maximum amylase production by the halophilic Micrococcus halobius, Halomonas meridiana, Halobacillus sp. Strain MA-2, Nesterenkonia sp. Strain F and Halomonas sp. AAD21 was exhibited at agitation rates of 140, 200, 200, 220 and $180 \mathrm{rpm}$ respectively (Onishi \& Sonoda, 1979; Coronado et al., 2000; Amoozegar et al., 2003; Shafiei et al., 2010; Uzyol et al., 2012).

\section{Effect of different carbon sources:-}

Although, strain $40^{\mathrm{T}}$ could secrete amylase constitutively, i.e. in the absence of a substrate, it was interestingly found that soluble starch, corn, rice, potato, wheat and beans starch as well as dextrin and glycogen enhanced amylase production strain. The highest amylase productivity was recorded for glycogen followed by rice starch (Fig 12). These natural substrates may be useful as cheaper alternative sources for halophilic amylase production. The other tested sources, i.e. carboxymethyl cellulose, glucose, lactose, maltose, sucrose, xylose, glycerol and mannitol did not enhance the amylase production by the strain. Amoozegar et al., (2003) investigated that the moderately halophilic Halobacillus sp. strain MA-2 produce amylase was in the presence of soluble starch, dextrin, maltose, sucrose, lactose, and glucose exhibiting its maximum productivity with dextrin followed by starch. Prakash et al., (2009) reported that few substrates, i.e. maltose and soluble starch induced amylase production by the halotolerant eubacterium Chromohalobacter TVSP 101. Halomonas sp. AAD21 produced amylase using soluble starch, sucrose, lactose, and potato starch as substrates (Uzyol et al., 2012).

\section{Effect of different nitrogen sources:-}

Comparing with the control; $\mathrm{NH}_{4} \mathrm{NO}_{3}$, casein, meat casein, tryptone, and fibrin inhibited productivity, while no effect of beef extract and nearly casamino acids. 
Other tested sources stimulated productivity in variable extents but the maximum was exhibited by yeast extract, followed by gelatin and then $\left(\mathrm{NH}_{4}\right)_{2} \mathrm{SO}_{4}$ (Fig. 13).

It was reported that the addition of inorganic nitrogen sources such as ammonium nitrate, sodium nitrate and ammonium sulfate reduced productivity but peptone exhibited the maximum productivity of amylase by the moderately halophilic bacterium Halomonas sp. strain AAD21 (Uzyol et al., 2012). The maximum productivity of amylase by the extremely halophilic archaeon Halobacterium halobium occurred when peptone was used as nitrogen source (Patel et al., 1993).

\section{Ideal conditions for maximum amylase production:-}

From studying the factors affecting amylase productivity by strain $40^{\mathrm{T}}$, the optimum nutritional and environmental requirements for maximum amylase production were as follows $(\%, \mathrm{w} / \mathrm{v}): \mathrm{NaCl}, 15$; soluble starch, $0.05 ; \mathrm{KCl}, 1.5$; $\mathrm{MgSO}_{4} .7 \mathrm{H}_{2} \mathrm{O}$; 0.1 ; $\mathrm{pH} 6-8$; inoculum size $8 \%$ (v/v) of $1 \times 10^{8} \mathrm{CFU} / \mathrm{ml}$; incubation period $48 \mathrm{~h}$, shaking rate, $150 \mathrm{rpm}$ and the incubation temperature $45-47^{\circ} \mathrm{C}$.

\section{Digestion of raw starches from different plant sources:-}

As it is shown in (Fig. 14), the present amylase could hydrolyze all tested raw starches, mentioned above. Compared with soluble starch as a control, it was found that corn, wheat and bean were hydrolyzed at the same degree of soluble starch hydrolysis. Amylase exhibited the maximum effect in case of rice as a substrate, while potato starch was less hydrolyzed, because potato starch is hardly digested by amylases because of the larger size of its granules (Hamilton et al., 1999; Nidhi et al., 2005). It is known that corn, wheat and rice are among the main cereals used for the preparation of fermented foods and beverages (KyalAkond, 2005). Subsequently, it is suggested that the present amylase can be used in the first stage of industrial starch hydrolysis instead of using chemicals such as hydrochloric acid, as enzymatic pre-treatment of rice starch as the first step in rice wine preparation process to produce dextrins and reducing sugars which could be, later, fermented by yeast to produce alcohol.

\section{Legend figures}

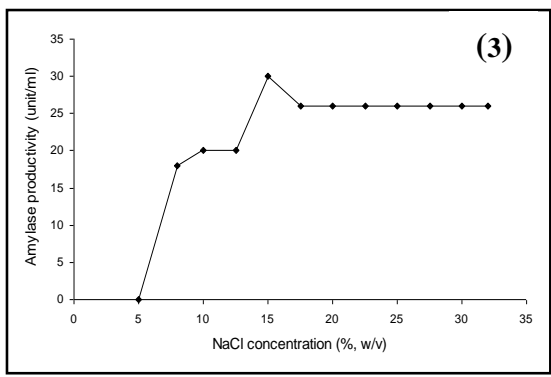

Fig.3. Effect of $\mathrm{NaCl}$ concentration

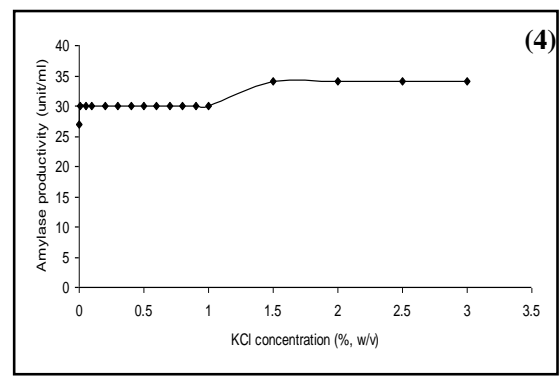

Fig.4. Effect of $\mathrm{KCl}$ concentration 


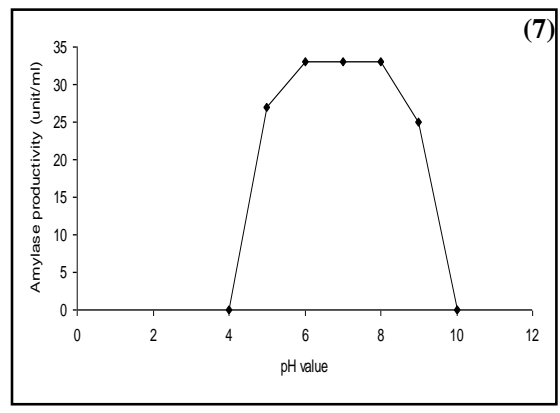

Fig.5. Effect of $\mathrm{MgSO}_{4} \cdot 7 \mathrm{H}_{2} \mathrm{O}$ concentration

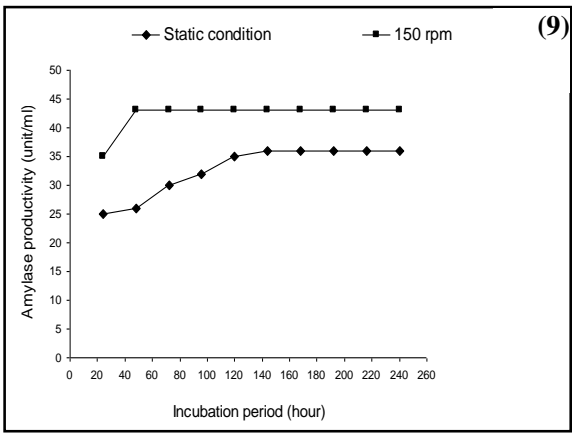

Fig.7. Effect of pH

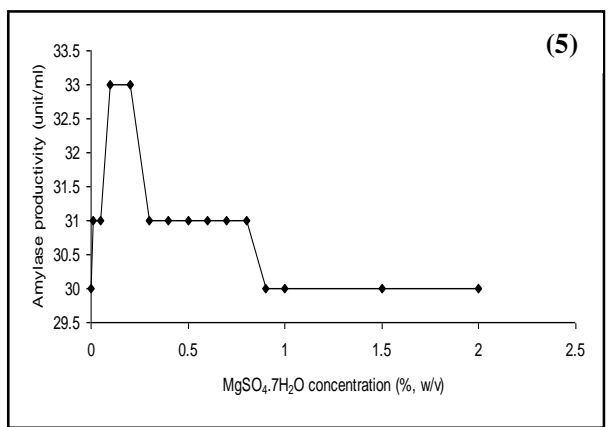

Fig.9. Effect of incubation period

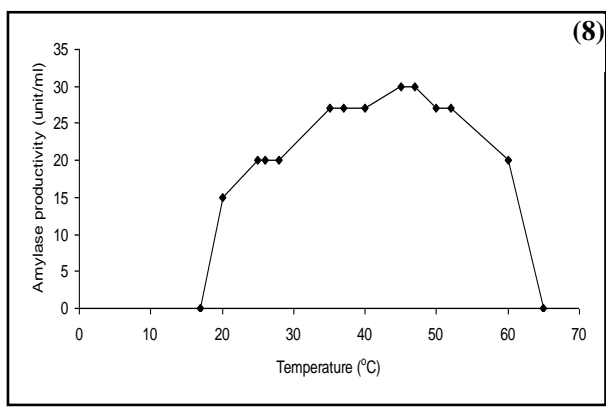

Fig.6. Effect of substrate concentration

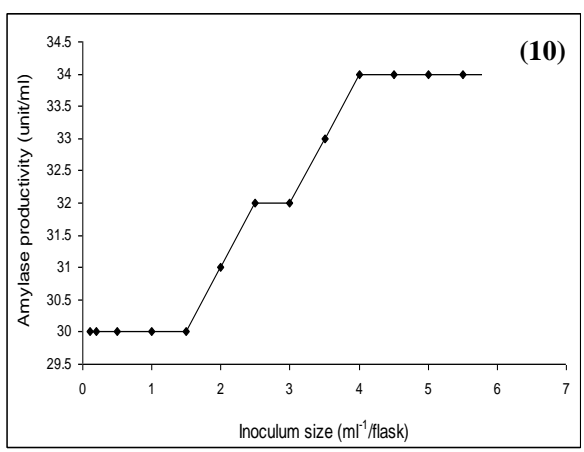

Fig. 8. Effect of incubation temperature

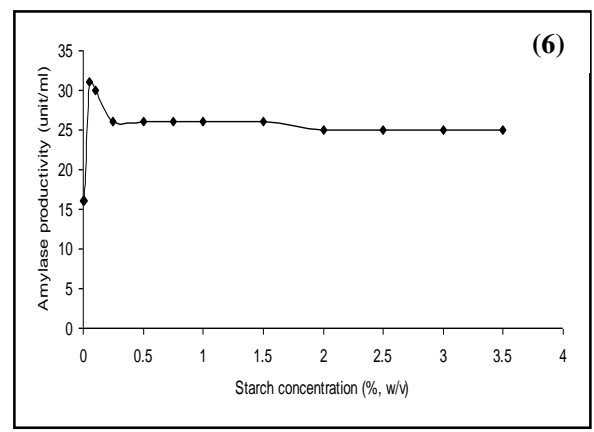

Fig.10. Effect of inoculum size 


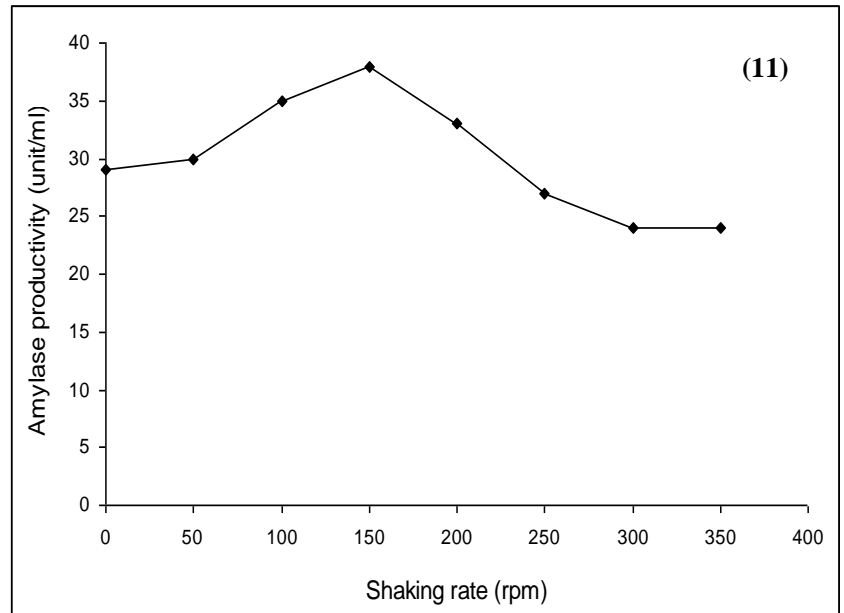

Fig.11. Effect of shaking rate

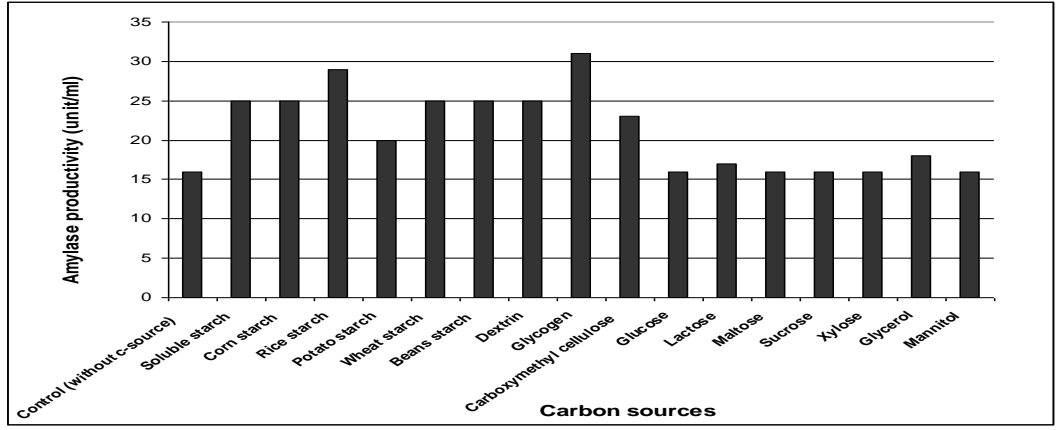

Fig. 12. The effect of different carbon sources on amylase productivity by strain $40^{T}$

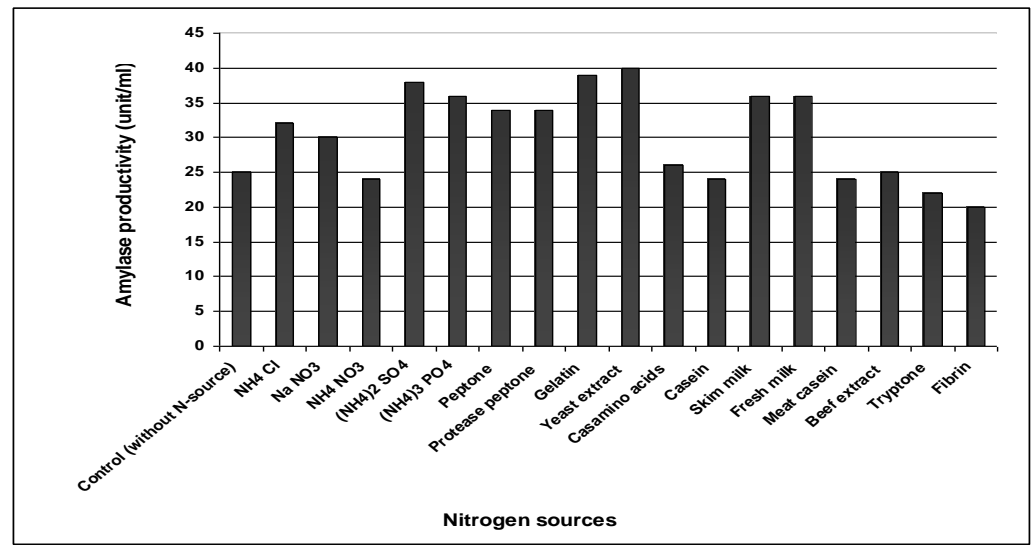

Fig.13. The effect of different nitrogen sources on amylase productivity by strain $40^{\mathrm{T}}$ 


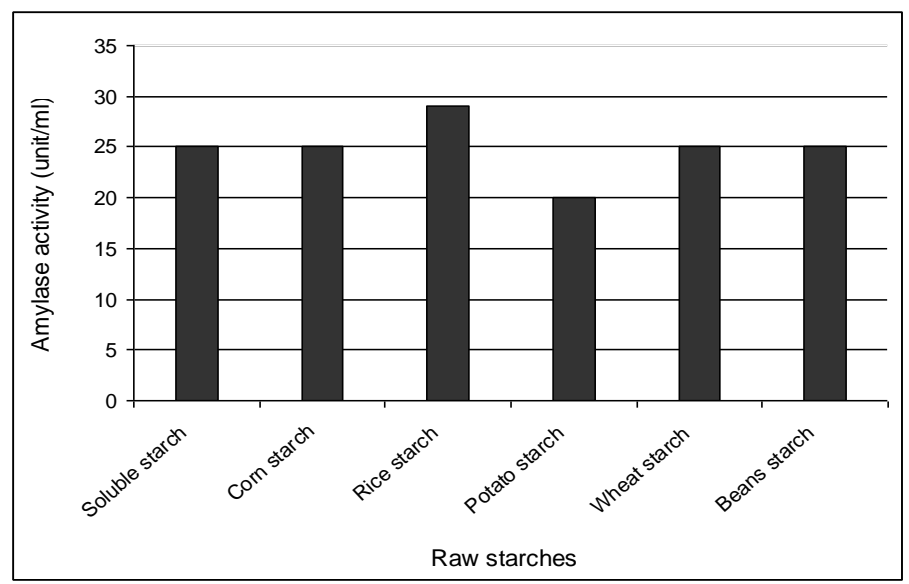

Fig.14. Digestion of raw starches from different plant sources by the crude amylase

\section{References}

1. Ammar, M. S., El-Ssaway, M., Yassin, M. \& Sherif, Y. M. (1998). Hydrolytic enzymes of fungi isolated from certain Egyptian antiquities objects while utilizing the industrial wastes of sugar and integrated industries company (SIIC), Egypt. J. Biotechnol. 3: 60-90.

2. Amoozegar, M. A., Malekzadeh, F. \& Malik, K. A. (2003). Production of amylase by newly isolated moderate halophile, Halobacillus sp. strain MA-2. J. Microbiol. Methods 52 (3): 353-359.

3. Beg, Q. K., Sahai, V. \& Gupta, R. (2003). Statistical media optimization and alkaline protease production from Bacillus mojavensis in a bioreactor. Process Biochemistry 39 (2): 203-209.

4. Brown, H. J. \& Gibbons, N. E. (1955). The effect of magnesium, potassium and iron on the growth and morphology of red halophilic bacteria. Can. J. Microbiol. 1: 486-494.

5. Coronado, M. J., Vargas, C., Hofemeister, J., Ventosa, A. \& Nieto, J. J. (2000). Production and biochemical characterization of an $\alpha$-amylase from the moderate halophile Halomonas meridian. FEMS Microbiology Letters 183: 67-71.

6. Couto, S. R. \& Sanromán, M. A. (2006). Application of solid-state fermentation to food industry. A review. Journal of Food Engineering 76: 291-302.

7. Cowan, S. T. (1974). Cowan and Steel's Manual For The Identification of Medical Bacteria. $2^{\text {nd }}$ ed. Cambridge University, Press, London.

8. Elwan, S. H., Ammar, M. S. \& El-Moussallamy, M. K. (1986). Relation of the production of Penicillum chrysogenum lipase to $\alpha$-amylase biosynthesis and some factors affecting the crude lipase activity. Egypt J. Microbiol. 21 (2): 129-142.

9. Francis, F., Sabu, A., Nampoothiri, K. M., Ramachandran, S., Ghosh, S., Szakacs, G. \& Pandey, A. (2003). Use of response surface methodology for optimizing process parameters for the production of $\alpha$-amylase by Aspergillus oryzae. Biochem. Eng. J. 15: $107-115$. 
10. Friedrich, J., Cimerman, A. \& Steiner, W. (1989). Submerged production of pectinolytic enzymes by Aspergillus niger: effect of different aeration/agitation regimes. Appl. Microbiol. Biotechnol. 31: 490-494.

11. Fukushima, T., Mizuki, T., Echigo, A., Inoue, A. \& Usami, R. (2005). Organic solvent tolerance of halophilic $\alpha$-amylase from a haloarchaeon, Haloarcula sp. strain S-1. Extremophiles 9: 85-89.

12. Gibbons, N. E. (1969). Isolation, growth and requirements of halophilic bacteria. In: Norris, J. R. \& Ribbons, D. W. (eds.), Methods in Microbiology, vol. 3 B. Academic Press, New York, pp. 169-183.

13. Good, W. A. \& Hartman, P. A. (1970). Properties of the amylase from Halobacterium halobium. J. Bacteriol. 104: 601-603.

14. Gupta, R., Gigras, P., Mohapatra, H., Goswami, V. K. \& Chauhan, B. (2003). Microbial $\alpha$-amylases: a biotechnological perspective. Process Biochem. 38: 1599-1616.

15. Gutiérrez, M. C., Castillo, A. M., Kamekura, M., Xue, Y., Ma, Y., Cowan, D. A., Jones, B. E., Grant, W. D. \& Ventosa, A. (2007). Halopiger xanaduensis gen. nov. sp. nov., an extremely halophilic archaeon isolated from saline lake Shangmatala in Inner Mongolia, China. Int. J. Syst. Evol. Microbiol. 57: 1402-1407.

16. Hamilton, L. M., Kelly, C. T. \& Fogarty, W. M. (1999). Purification and properties of the raw starch degrading amylase of Bacillus sp. IMD434. Biotechnol. Lett. 21: 111-115.

17. Hezayen, F. F. (2002). Biotechnological, taxonomical and enzymatic studies on biopolymers producing extremely halophilic archaea isolated from Egypt. Ph.D. Thesis. Der Westfälischen Wilhelms-Universität Münster, Germmany.

18. Hezayen, F. F., Rehm, B. H. A., Tindall, B. J. \& Steinbüchel, A. (2001). Transfer of Natrialba asiatica B1T to Natrialba taiwanensis sp. nov., and description of Natrialba aegyptiaca sp. nov., a novel extremely halophilic, aerobic, non-pigmented member of the archaea from Egypt which produces extracellular poly (glutamic acid). Int. J. Syst. Evol. Microbiol. 51: 1133-1142.

19. Horváthová, V., Janeček, S. \& Šturdik, E. (2000). Amylolytic enzymes: their specificities origins and properties. Biologia, Bratislava 55 (6): 605-615.

20. Hutcheon, G. W., Vasisht, N. \& Bolhuis, A. (2005). Characterization of a highly stable $\alpha$ amylase from the halophilic archaeon Haloarcula hispanica. Extremophiles 9: 487-495.

21. Jones, R. A., Jermiin, L. S., Easteal, S., Patel, B. K. C. \& Beacham, I. R. (1999). Amylase and 16S rRNA genes from a hyperthermophilic archaebacterium. J. Appl. Microbiol. 86:93-107.

22. Kobayashi, K., Kanai, H., Hayashi, T., Akiba, T., Akaboshi, r. \& Horikoshi, K. (1992). Haloalkaliphilic maltotriose-forming alpha-amylase from the archaebacterium Natronococcus sp. strain Ah-36. J. Bacteriol. 174: 3439-3444.

23. Kumar, C. G. \& Takagi, H. (1999). Microbial alkaline proteases: from a bioindustrial viewpoint. Biotechnology Advances 17 (7): 561-594.

24. Kushner, B. J. (1985). The Halobacteriaceae. In: Woese and Wolfe (Eds.), The Bacteria: A Treatise on Structure and Function, vol. Vш, The Archaeabacteria. New York: Academic Press, pp. 171-214. 
25. Kushner, D. J. \& Kamekura, M. (1988). Physiology of halophilic eubacteria, p. 109-138. In: Rodriguez-Valera, F. (ed.), Halophilic bacteria, vol. 1. CRC Press, Ine. Boca Raton, Fla.

26. KyalAkond, A. (2005). Studies on preparation of rice wine. Master Thesis. Depart. Agricul. Microbiol. Collage of Agriculture, Dharwad. University of Agricultural Sciences, Dharwad.

27. Lanyi, J. K. (1974). Salt-dependent properties of proteins from extremely halophilic bacteria. Bacteriol. Rev. 38: 272-290.

28. Madern, D., Ebel, C. \& Zaccai, G. (2000). Halophilic adaptation of enzymes. Extremophiles 4: 91-98.

29. Marhuenda-Egea, F. C. \& Bonete, M. J. (2002). Extreme halophilic enzymes in organic solvents. Curr. Opin. Biotechnol. 13: 385-389.

30. Matheson, A. T., Sprott, G. D., Mc Donald, I. J. \& Tessier, H. (1976). Some properties of an unidentified halophile: growth characteristics, internal salt concentration and morphology. Can. J. Microbiol. 22: 780-786.

31. Montalvo-Rodriguez, R., Vreeland, R. H., Oren, A., Kessel, M., Betancourt, C. \& LópezGarriga, J. (1998). Halogeometricum borinquense gen. nov. sp. nov., a novel halophilic archaeon from Puerto Rico. Int. J. Syst. Bacteriol. 48: 1305-1312.

32. Nidhi, G., Gupta, J. K. \& Soni, S. K. (2005). A novel raw starch digesting thermostable $\alpha-$ amylase from Bacillus sp. I-3 and its use in the direct hydrolysis of raw potato starch. Enzyme Microb. Technol. 37: 723-734.

33. Niehaus, F., Bertoldo, C., Kahler, M. \& Antranikian, G. (1999). Extremophiles as a source of novel enzymes for industrial application. Appl. Microbiol. Biotechnol. 51: 711729.

34. Norberg, P., Kaplan, J. G. \& Kushner, D. J. (1973). Kinetics and regulation of saltdependent aspartate transcarbamylase of Halobacterium cutirubrum. J. Bacteriol. 113: 680-686.

35. Onishi, H. \& Sonoda, K. (1979). Purification and some properties of an extracellular amylase from a moderate halophile Micrococcus halobius. Appl. Environ. Microbiol. 38 (4): 616-620.

36. Oren, A. (1983). Halobacterium sodomense sp. nov., a Dead sea halobacterium with an extremely high magnesium requirement. Int. J. Syst. Bacteriol. 33: 381-386.

37. Pandey, A., Nigam, P., Soccol, C. R., Soccol, V. T., Singh, D. \& Mohan, R. (2000). Advances in microbial amylases. Biotechnol. Appl. Biochem. 31: 135-152.

38. Pantschev, C., Klenz, C. \& Hafner, B. (1981). Vergleichende characterrisierung von alpha-amylase preparaten. Lebensmittel industrie 28: 71-74.

39. Patel, S., Jain, N. \& Madamwar, D. (1993). Production of $\alpha$-amylase from Halobacterium halobium. World J. Microbiol. Biotechnol. 9: 25- 28.

40. Pérez-Pomares, F., Bautista, V., Ferrer, J., Pire, C., Marhuenda-Egea, F. C. \& Bonete, M. J. (2003). $\alpha$-amylase activity from the halophilic archaeon Haloferax mediterranei. Extremophiles 7: 299-306.

41. Prakash, B., Vidyasagar, M., Madhukumar, M. S., Muralikrishna, G. \& Sreeramulu, K. (2009). Production, purification and characterization of two extremely halotolerant, 
thermostable and alkali-stable $\alpha$-amylases from Chromohalobacter sp. TVSP101. Process Biochemistry 44: 210-215.

42. Rajagopalan, G. \& Krishnan, C. (2008). Alpha-amylase production from catabolite derepressed Bacillus subtilis KCC103 utilizing sugarcane bagasse hydrolysate. Bioresour. Technol. 99: 3044-3050.

43. Roychoudhury, S., Parulekar, S. J. \& Weigand, W. A. (1988). Cell growth and $\alpha$-amylase production, characteristics of Bacillus amyloliquefaciens. Biotechnol. Bioeng. 33: 197206.

44. Sajedi, R. H., Naderi-Manesh, H., Khajeh, K., Ahmadvand, R., Ranjbar, B., Asoodeh, A. $\&$ Moradian, F. (2005). A Ca-independent $\alpha$-amylase that is active and stable at low $\mathrm{pH}$ from the Bacillus sp. KR-8104. Enzyme Microb. Technol. 36: 666-671.

45. Saxena, R. K., Dutt, K., Agarwal, L. \& Nayyar, P. (2007). A highly thermostable and alkaline amylase from a Bacillus sp. PN5. Bioresour. Technol. 98: 260-265.

46. Shafiei, M., Ziaee, A-A. \& Amoozegar, M. A. (2010). Purification and biochemical characterization of a novel SDS and surfactant stable, raw starch digesting, and halophilic $\alpha$-amylase from a moderately halophilic bacterium Nesterenkonia sp. strain F. Process Biochem. 45: 694-699.

47. Tindall, B. J., Ross, H. N. M. \& Grant, W. D. (1984). Natronobacterium gen. nov., and Natronococcus gen. nov., two new genera of haloalkaliphilic archaebacteria. Syst. Appl. Microbiol. 5 (1): 41-57.

48. Tomlinson, G. A. \& Hochstein, L. I. (1972). Isolation of carbohydrate-metabolizing extremely halophilic bacteria. Can. J. Microbiol. 18: 698-701.

49. Uzyol, K. S., Akbulut, B. S., Denizci, A. A. \& Kazan, D. (2012). Th ermostable $\alpha-$ amylase from moderately halophilic Halomonas sp. AAD21. Turk J. Biol. 36: 327-338.

50. Ventosa, A. (2006). Unusual microorganisms from unusual habitats: hypersaline environments. In Prokaryotic Diversity: Mechanisms and Significance (Society for General Microbiology Symposium no. 66), pp. 223-253. Edited by N. A. Logan, H. M. Lappin-Scott \& P. C. F. Oyston. Cambridge: Cambridge University Press.

51. VijayAnand, S., Hemapriya, J., Selvin, J. \& Kiran, S. (2010). Production and optimization of haloalkaliphilic protease by an extremophile Halobacterium sp. JS1, isolated from Thalassohaline environment. Global J. Biotechnol. Biochem. 5 (1): 44-49.

52. Windish, W. W. \& Mhatre, N. S. (1965). Microbial amylases. In: Wayne, W. U. (Ed.). Advances in Applied Microbiology. Vol. 7. New York: Academic Press, pp. 273-304.

53. Xin, H., Itoh, T., Zhou, P., Suzuki, K., Kamekura, M. \& Nakase, T. (2000). Natrinema versiforme sp. nov., an extremely halophilic archaeon from Aibi salt lake, Xinjiang, China. Int. J. Syst. Evol. Microbiol. 50: 1297-1303.

54. Xu, Y., Wang, Z., Xue, Y., Zhou, P., Ma, Y., Ventosa, A. \& Grant, W. D. (2001). Natrialba hulunbeirensis sp. nov., and Natrialba chahannaoensis sp. nov., novel haloalkaliphilic archaea from Soda lakes in Inner Mongolia Autonomous Region, China. Int. J. Syst. Evol. Microbiol. 51: 1693-1698.

55. Zaccai, G. \& Eisenberg, H. (1990). Halophilic proteins and the influence of solvent on protein stabilization. Trends Biochem. Sci. 9: 333-337. 
